\title{
Adrenalectomy in dogs: retrospective study of 13 cases performed in Universidade Anhembi Morumbi Veterinary Hospital (2012-2015)
}

\author{
Adrenalectomia em cães: estudo retrospectivo de 13 casos realizados \\ no hospital veterinário da Universidade Anhembi Morumbi (2012 a 2015)
}

\author{
Tatiana PACINI ${ }^{1}$; Márcia Marques JERICÓ ${ }^{1}$; Livia Povinha SCALIZE ${ }^{1}$; Adriana Tomoko NISHIYA ${ }^{1}$ \\ ${ }^{1}$ Universidade Anhembi Morumbi, São Paulo - SP, Brazil
}

\begin{abstract}
Adrenalectomy is the most appropriate treatment for unilateral adrenal tumors. This study aimed at describing the epidemiological characteristics and perioperative behavior of canine patients submitted to adrenalectomy at Anhembi Morumbi Veterinary Hospital. Out of 13 dogs, eight were pure breeds and five were mixed breeds; 12 females, aged $9.5 \pm 2.5$ years old. Regarding the tumors, seven were located on the right and histopathological analysis revealed cortical adenoma in 11 and adenocarcinomain only two dogs. Two cases had hypercortisolism recurrenceassociated with hyperplasia in the contralateral adrenal, as confirmed by ACTH stimulation test. The results of this study indicate that adrenalectomy is a safe procedure with few perioperative complications, despite the possibility of hypercortisolism recurrence.
\end{abstract}

Keywords: Dogs. Adrenalectomy. Hyperadrenocorticism. Adenoma. Adenocarcinoma.

\section{Resumo}

Adrenalectomia é o tratamento mais indicado para neoplasias adrenais unilaterais. Objetivou-se descrever os aspectos epidemiológicos e o comportamento perioperatório em cães submetidos a adrenalectomia no Hospital Veterinário Anhembi Morumbi. Dos 13 casos, oito eram cães de raças puras e cinco eram SRD; 12 eram fêmeas e de idade de 9,5 \pm 2,5 anos. Das massas adrenais, sete eram em lado direito. Os exames histopatológicos revelaram adenoma cortical em 11 cães e adenocarcinoma em dois. Dois casos recidivaram a condição de hipercortisolemia, associada à hiperplasia, na adrenal contralateral, confirmados pelo teste de estimulação por ACTH. Concluiu-se que a adrenalectomia é um procedimento seguro, com poucas complicações perioperatórias, ressalvando-se a possiblidade de recidiva do quadro de hipercortisolismo. Palavras-chave: Cães. Adrenalectomia. Hiperadrenocorticismo. Adenoma. Adenocarcinoma.

Correspondence to:

Tatiana Pacini

Universidade Anhembi Morumbi

R. Dr. Almeida Lima, 1134 - Parque da Mooca

CEP 03164-000, São Paulo, SP, Brazil

e-mail: tatiana.pacini@gmail.com

Received: $14 / 01 / 2016$

Approved: 12/05/2017

\section{Introduction}

Primary adrenal neoplasms are not rare and are the cause of hypercortisolemia in $10 \%$ to $20 \%$ of the cases overall (DAVIS et al., 2012). The most commonly found primary adrenal tumors are adenomas and adenocarcinomas, followed by pheochromocytoma and others, which are the minority (FELDMAN, 2008; FRANKOT et al., 2012).
A reliable and accurate diagnosis of the adrenal neoformation requires careful clinical monitoring and laboratory tests, which must include blood pressure, complete blood count, complete urinalysis (with microbial culture) and serum biochemical profile. Specific tests of adrenal function, such as measurement of urinary steroids (urinary cortisol/creatinine ratio), cortisol before and after ACTH stimulation test and suppression test with lowdose dexamethasone are also required (CAPEN, 2007; FELDMAN, 2008; NELSON, 2010).

Endogenous ACTH concentration test is also recommended to differentiate the origin of hypercortisolemia, as it may be (adrenocorticotropic) primary or (pituitary) ACTH-dependent (NELSON, 2010; BEHREND et al., 2013). Its measurement is a good indication source when hypercortisolism diagnosis 
has already been established. Endogenous ACTH levels tend to be normal to elevated in cases of ACTHdependent hypercortisolism and are generally low or undetectable in dogs with adrenal tumors or iatrogenic hyperadrenocorticism (SCHIMMER; PARKER, 2007; BRÖMEL et al., 2013). The reference values vary depending on the technique used; thus, they vary between the levels established by each laboratory (BEHREND et al., 2013).

Abdominal ultrasound is initially used to assess the adrenal gland to evaluate the size and symmetry of the glands; in visualization, measurement and echogenicity of tumor masses and, finally, for an overall scanning of the abdomen, especially areas adjacent to the adrenals to investigate the presence of possible metastasis. If the abdominal ultrasound confirms the presence of a mass in the adrenal topography, plain and contrasted abdominal CT scans are necessary. Chest $\mathrm{x}$-rays should be evaluated for evidence of pulmonary metastasis of an adrenocortical carcinoma (CAPEN, 2007; NELSON, 2010). Computed tomography and magnetic resonance imaging disclose the presence of pituitary tumors larger than $1 \mathrm{~cm}$ and these are the most accurate tests for investigating the source of hypercortisolism and obtaining images of the adrenal gland (BEHREND et al., 2013).

Currently, adrenalectomy is the treatment of choice for unilateral adrenal tumors (PELÁEZ et al., 2008; NELSON, 2010; LANG et al., 2011). However, adrenalectomy is associated with a high rate of perioperative mortality in dogs (SCHWARTZ et al., 2008). On the other hand, Massari et al. (2011) found a mean survival time greater than 10 months, postoperatively.

Reported complications associated with adrenalectomy in dogs include fluid and electrolyte imbalances, postsurgical adrenal gland failure, bleeding, hypotension, arrhythmias, pulmonary thromboembolism, disseminated intravascular coagulation, pancreatitis and acute renal failure. Wound infection and dehiscence may be observed, due to the negative effects of steroids on wound healing (LANG et al., 2011; BARRERA et al., 2013; FOSSUM, 2013).

It has been generally accepted that the long-term prognosis of post-adrenalectomy is favorable, considering that the animal survived the perioperative period. Identifying the factors that currently influence the perioperative mortality can be useful to guide treatment recommendations (LANG et al., 2011).

Other important factors to consider are tumor relapse cases, as well as adrenal hyperfunction after adrenalectomy, but there are a few specific studies on the subject. Related to adrenalectomy in dogs with hyperadrenocorticism caused by adrenocortical tumors, Van Sluijs et al. (1995) reported a small but substantial hypercortisolemia recurrence development index after adrenalectomy, confirmed by measuring urinary cortisol or cortisol suppression by dexamethasone. Moreover, there is the possibility of occurrence of metastases, which also result in the recurrence of the clinical state (LANG et al., 2011).

\section{Objectives}

Based on the data raised, particularly regarding the scarce information on the subject, this project aimed to describe the epidemiological characteristics and perioperative behavior of dogs submitted to adrenalectomy at Anhembi Morumbi Veterinary Hospital (HOVET), from January 2012 to July 2015. Project goals included determining which major complications were observed in these patients, the current health status of the animals, as well as assessing the incidence of adrenal hyperfunction recurrence, treatment employed and the animals individual response to treatment, with the objective of aiding development of adequate prognosis when adrenalectomy was indicated as treatment protocol.

\section{Methods}

A retrospective quantitative descriptive study (January 2012 to July 2015) was carried out by evaluating records of patients submitted to the surgical procedure of adrenalectomy at HOVET to analyze and collect the data. Owners of animals submitted to the procedure without regular or recent appointments at Anhembi Morumbi HOVET were contacted by telephone to determine the animal's current health status. During the retrospective search, the following were documented: patient species, breed, age, gender, diagnosis and pre-surgical management; surgical outcomes; results of histopathological exam; assessment of the current health status of the animals and how many of these animals had shown contralateral or pituitary-dependent hyperadrenocorticism recurrence after the adrenalectomy, as well as how long it took the animal to have this recurrence, protocols employed for the diagnosis and treatment of the condition.

\section{Development and Results}

A retrospective quantitative descriptive study was carried out through analysis of the medical records of patients submitted to adrenalectomy. Telephone contact was made with 13 owners to update the medical history 
and investigate the animals' current health status. Data were collected in a spreadsheet to be analyzed.

Of the 13 animals, eight were of pure breeds - Lhasa Apso (two), Shih-Tzu (two), English Cocker Spaniel (one),
Labrador Retriever (one), Maltese (one) and Poodle (one) - and five were mixed-breed; 12 were females. Mean age was $9.5 \pm 2.5$ years. Mean body weight was $22.1 \pm 18.5 \mathrm{~kg}$ (Table 1).

Table 1 - General characteristics of dogs that underwent adrenalectomy at the Anhembi Morumbi Veterinary Hospital - São Paulo, Brazil - 2012-2015

\begin{tabular}{|c|c|c|c|c|}
\hline Dog & Signalment & Signs & $\begin{array}{l}\text { Affected } \\
\text { Adrenal }\end{array}$ & $\begin{array}{l}\text { Preview } \\
\text { Treatment }\end{array}$ \\
\hline 1 & Mixed Breed; 9 years; female; 19 kg & $\begin{array}{l}\text { polyphagia; polydipsia; polyuria; bulging abdomen; } \\
\text { telangiectasia }\end{array}$ & Right & Trilostane \\
\hline 2 & Poodle 11 years; female; 7.5 kg & $\begin{array}{l}\text { polyphagia; polydipsia; polyuria; bulging abdomen; } \\
\text { telangiectasia }\end{array}$ & Left & Mitotane \\
\hline 3 & Mixed Breed; 8 years; female; 5 kg & polyphagia; polydipsia & Left & $x$ \\
\hline 4 & Mixed Breed; 11 years; female; 15.4 kg & $\begin{array}{l}\text { polyphagia; polydipsia; polyuria; bulging abdomen; } \\
\text { telangiectasia }\end{array}$ & Left & $x$ \\
\hline 5 & $\begin{array}{l}\text { Cocker Spaniel; } 12 \text { years; male; } 19.5 \\
\text { kg }\end{array}$ & $\begin{array}{l}\text { polyphagia; polydipsia; polyuria; bulging abdomen; } \\
\text { telangiectasia }\end{array}$ & Left & Trilostane \\
\hline 6 & Lhasa Apso; 12 years; female; $4.2 \mathrm{~kg}$ & $\begin{array}{l}\text { polyphagia; polydipsia; polyuria; bulging abdomen; } \\
\text { telangiectasia }\end{array}$ & Right & Trilostane \\
\hline 7 & Labrador; 12 years; female; $31.6 \mathrm{~kg}$ & polyphagia; polydipsia; polyuria; bulging abdomen & Left & $x$ \\
\hline 8 & Mixed Breed; 11 years; female; 40.6 kg & No signs reported & Left & $x$ \\
\hline 9 & Lhasa Apso; 9 years; female; 11.2 kg & $\begin{array}{l}\text { polyphagia; polydipsia; polyuria; bulging abdomen; } \\
\text { telangiectasia }\end{array}$ & Right & $x$ \\
\hline 10 & Shih-Tzu; 9 years; female; 8.7 kg & $\begin{array}{l}\text { polyphagia; polydipsia; polyuria; bulging abdomen; } \\
\text { telangiectasia }\end{array}$ & Right & Trilostane \\
\hline 11 & Shih-Tzu; 8 years; female; 7.6 kg & polyphagia; polydipsia & Right & Trilostane \\
\hline 12 & Mixed Breed; 10 years; female; 10.5 kg & polyphagia; polydipsia; polyuria & Right & Trilostane \\
\hline 13 & Maltês; 7 years; female; 3.6 kg & polyphagia; polydipsia; polyuria & Right & $\mathrm{x}$ \\
\hline
\end{tabular}

The main clinical signs observed at the animals' clinical presentation related to the diagnosis of hypercortisolism were polyuria and polydipsia (12), polyphagia (10), bulging abdomen (eight) and telangiectasia (seven), as shown in table 1. At the laboratory tests, a complete blood count showed thrombocytosis in four animals, with values ranging from 556.000 to 670.000 platelets $/ \mu \mathrm{L}$. The biochemical tests showed great levels of AP in eight dogs (176-8099 U.I./L), ALT in seven dogs (106-520 U.I./L), hypertriglyceridemia in eight of the dogs $(102-357.6 \mathrm{mg} / \mathrm{dL})$ and hypercholesterolemia in seven dogs (288-393 mg/dL). Systemic arterial hypertension was observed in four dogs (Systolic Blood Pressure: 160-213 mmHg, monitored indirectly by Doppler system.). Only seven of the 13 animals had urinalysis performed and of these, four animals had specific urinary gravity within reference parameters and three had decreased gravity, ranging from 1.012 to 1.018 .

At the preoperative assessment, alterations found in the echocardiography were mild to moderate mitral valve regurgitation (four) and significant mitral and tricuspid valve regurgitation (one). ECG revealed ventricular repolarization disorder in one dog. Other nonpathological alterations found were sinus arrhythmia with pacemaker migration (two), and sinus arrhythmia (one).

The imaging assessment of the affected adrenal glands showed that, seven were on the right and six on the left side (Table 1). It was also observed a prevalence of an increase in the gland caudal pole thickness. Eight of the 13 patients underwent CT scan and one was referred to MRI. All nine animals showed heterogeneous contrast medium enhancement (ranging from moderate, marked or intense), with no significant difference between mass benignity and malignancy.

Of the 13 animals, six had previously been treated with trilostane, with doses of $1.1 \mathrm{mg} / \mathrm{kg} \pm 0.4$ every 12 hours (five) and once daily (one); one animal received previous treatment with mitotane at a dose of $25 \mathrm{mg} / \mathrm{kg}$ every 12 hours (Table 1 ). 
All adrenalectomies were performed using the open ventral midline laparotomy technique; one animal had an additional paracostal incision, to extend the access area. One animal had tumor invasion of the inferior vena cava wall and one dog had the adrenal gland adhered to the renal artery; both were successfully submitted to gland resection, with no occurrence of bleeding. Of the 13 animals, six had other procedures performed at the same surgery: cholecystectomy (one), liver biopsy in the left lobe and excisional biopsy of a node in the right lower eyelid (one), excisional biopsy of lymph node near the left adrenal gland (one), cauterization of a wart on the right pelvic limb (one), partial lobectomy of the left lateral liver lobe (one), excisional nodule biopsy in the right thoracic breast (one).

Regarding the transoperative complications (Figure 1), hypotension was observed in three dogs, one case with mild episodes of bradycardia, compensatory hypotension and sporadic ventricular escape at the electrocardiogram, but no pharmacological intervention was required; a case of hypotension unresponsive to increased fluid rate or atropine and reversed with continuous infusion of dopamine; a case of hypotension initially reversed with an increase in the fluid infusion rate to $20 \mathrm{~mL} / \mathrm{kg} / \mathrm{hour}$, and subsequently reversed by continuous infusion of dopamine. The other transoperative complications observed were hypertension (one), hyperglycemia (one) and adrenal gland rupture during resection with leakage of large amounts of necrotic material in the cavity (one). One animal had seizures in the immediate postoperative period with loss of motor coordination; however, the seizures did not require pharmacological intervention.
All animals were admitted for post-surgical care, most of them remaining for a maximum period of 72 hours. During this period, all of them received prednisone $(0.6 \pm 0.4 \mathrm{mg} / \mathrm{kg})$ for 3 to 7 days, as well as antibiotics and analgesia. None of the dogs presented hypofunction or failure of the contralateral adrenal gland verified by the general state of the dogs and follow up serum cortisol analysis.

The main complaints during subsequent consultations post-adrenalectomy (Figure 2) were persistence of polyuria and polydipsia (10), hyporexia (seven) and vomiting (four). Two cases had reaction to the suture - one mild case in the first postoperative month, which did not require drug intervention and one case with fistulae for a few months' post-adrenalectomy, which was treated with antibiotic therapy. One animal died 23 days after the surgery due to necrosis of the incision and surrounding tissue, followed by abdominal evisceration.

Histopathological analysis showed adrenal gland cortical adenoma in eleven dogs and adrenal gland cortical adenocarcinoma in only two of the investigated cases. Both were large females (Labrador Retriever and mixed-breed), aged 11 and 12 years, and with masses located in the left adrenal gland. One case had a previous diagnosis of hyperadrenocorticism, with moderate clinical symptoms and treatment with trilostane. The second case had the adrenal tumor identified at tests requested by emergency care after a syncope; the animal showed no obvious clinical signs of hyperadrenocorticism. The owners of both dogs denied any clinical signs related to hyperadrenocorticism 6 to 8 months' post-adrenalectomy.

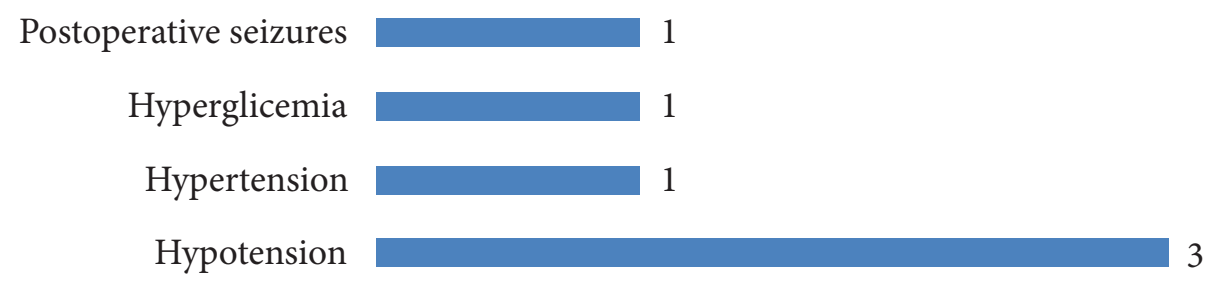

Figure 1 - Peri and transoperative complications documented in 13 assessed cases of adrenalectomy performed in dogs at the Anhembi Morumbi Veterinary Hospital (2012-2015)

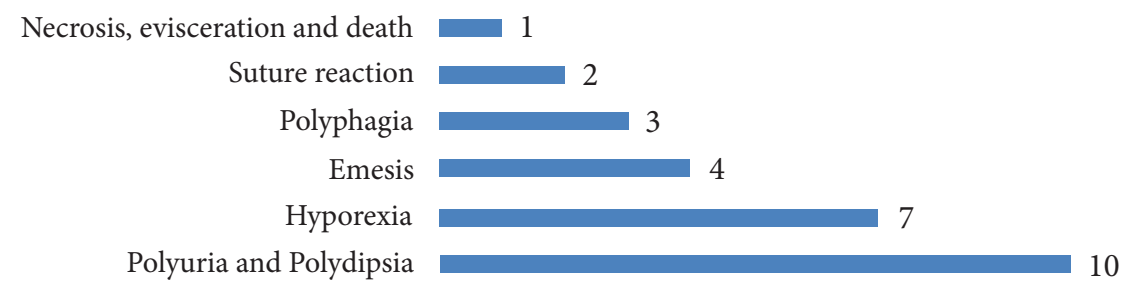

Figure 2 - Post-adrenalectomy complaints observed in dogs during the first three postoperative follow up consultations at the Anhembi Morumbi Veterinary Hospital (2012-2015) 
Four of the 13 dogs had endogenous ACTH measured before admission to surgery, two of the animals had results below the levels considered normal by the laboratory reference values ( 8 and $8.9 \mathrm{pg} / \mathrm{mL}$ ), suggesting adrenal gland tumor, and two had values within the normal range (15.3 and $38.3 \mathrm{pn} / \mathrm{mL}$ ). Histopathological test results of the four animals showed adrenal cortical adenoma and none of these has had symptoms related to recurrence to date.

Of the 13 cases analyzed, two had hypercortisolism recurrence associated with hyperplasia in the contralateral adrenal (both cases in the right adrenal), five to 11 months' post-adrenalectomy, as demonstrated by the symptoms and the ACTH stimulation test. Both are currently being treated with trilostane to control the disease.

\section{Discussion}

During the investigation of the 13 cases involved in this study, the highest incidence of hypercortisolemia with neoformation was found in adrenal gland of females (11), as was also ascertained by Massari et al. (2011). On the other hand, Lang et al. (2011), Naan et al. (2013) and Andrade et al. (2014) showed a very similar incidence between males and females (55.5\% females). The ascertained breeds, there was a heterogeneous representation in the group, noting that Labradors were reported by Schwartz et al. (2008), Lang et al. (2011), Massari et al. (2011), Naan et al. (2013) and Andrade et al. (2014), followed by Shih-Tzus - Schwartz et al. (2008), Lang et al. (2011) and Massari et al. (2011). Throughout the literature, the condition has been reported to also occur in mixed breed's dogs (PELÁEZ et al., 2008; LANG et al., 2011; MASSARI et al., 2011; BARRERA et al., 2013; NAAN et al., 2013).

The main clinical alterations noted prior to the adrenalectomy do not differ from the literature. The main ones are polyuria and polydipsia, polyphagia and bulging abdomen. Biochemical analysis shows an increase in the levels of PA, ALT, triglycerides and cholesterol. Such changes are also reported by Peláez, Bouvy and Dupré (2008), Lang et al. (2011) and Andrade et al. (2014).

In imaging, as far as the side of the occurrence of the masses, Peláez et al. (2008) have evidenced four in left adrenal and three on the right. In 2011, Lang et al. reported in their study 32 on the left side and 29 on the right. In turn, Massari et al. (2011) reported 25 (48\%) in the right adrenal gland and $16(30.8 \%)$ at the left. This research presents seven masses on the right side and six on the left; therefore, not demonstrating a greater trend incidence in one of the adrenal glands.
Regarding the intraoperative complications, the most frequently observed is hypotension (LANG et al., 2011; MASSARI et al., 2011; BARRERA et al., 2013; ANDRADE et al., 2014). Three cases of hypotension were observed in this study, one of them along with bradycardia and compensatory ventricular escape. Hypotension is the most common anesthetic complication observed in patients and its pathogenesis can be multifactorial. It is often an adverse pharmacological effect of many sedatives, analgesics and anesthetics (intravenous and inhaled) which directly affect the heart rate, preload, afterload, myocardial contractility and / or systemic vascular resistance. These variables are closely associated with blood pressure; therefore, a change in either (alone or in combination) may affect blood pressure. Moreover, age, concomitant diseases and duration of anesthesia may predispose patients to present hypotension (IIZUKA et al., 2013; RUFFATO et al., 2015).

The other intraoperative complications observed are one case of hypertension, as also reported by Barrera et al. in 2013, which found 12 cases of hypertension of 86 investigated; adrenal gland rupture during resection with extravasation of large amounts of necrotic material into the cavity (one). One animal had seizures in the immediate postoperative period with loss of motor coordination, but it was an isolated episode and there was no need for pharmacological intervention.

Some well-known complications can be related to the hypofunction of the remaining adrenal gland, what can lead to an adrenal insufficiency crisis. This can be prevented with glucocorticoid supplementation using various protocols in the perioperative period described in all published studies (KYLES et al., 2003; PELÁEZ et al., 2008; MASSARI et al., 2011; LANG et al., 2011; NAAN et al., 2013). Peláez (2008), Massari et al. (2011) and Naan et al. (2013) all administered dexamethasone and the dosage varied from $0.05-1 \mathrm{mg} / \mathrm{kg}$, while Lang et al. (2011) administered hydrocortisone acetate $2 \mathrm{mg} / \mathrm{kg} / \mathrm{IV}$ or dexamethasone $(0.07 \mathrm{mg} / \mathrm{kg} \mathrm{IV})$ immediately after anesthetic induction. Massari et al. (2011), Lang et al. (2011) and Naan et al. (2013) described the administration of prednisone $1 \mathrm{mg} / \mathrm{kg}$ PO SID or BID with the dosage tapered and discontinued between 4 and 12 weeks. Peláez et al. (2008) chose to administer prednisolone $0.2 \mathrm{mg} / \mathrm{kg}$ PO BID with the dosage tapered and discontinued over 4-6 weeks. There was no referral of adrenal hypofunction on any of the researches.

Fossum (2013) suggested that glucocorticoid therapy should start before surgery in patients 
with hipercortisolemia which are undergoing adrenalectomy and described the therapy being possible with the administration of dexamethasone (0.1-0.2 mg/kg), Hydrocortisone Hemisuccinate ( $2 \mathrm{mg} /$ $\mathrm{kg}$ ) or Hydrocortisone Phosphate $(2 \mathrm{mg} / \mathrm{kg}) 1$ hour before surgery. Fossum also suggests as postoperative glucocorticoid supplementation protocol the administration of Dexamethasone (0,01-0,1 mg/kg IV or SC q 6-8 hrs for 1-3 days and then begin with prednisolone $(0,5 \mathrm{mg} / \mathrm{kg}$ q $12 \mathrm{hrs}$ for $2-3$ days, then slowly decrease the dose every 3 weeks to the lowest tolerated dose.

Wise and Boveri (2016) stated on his case review that, as commonly occurs, it was unknown if the remaining hypoplastic adrenal gland would be capable of producing sufficient glucocorticoid and one single postoperative dose of prednisolone was administered to provide supplementation for the recovery from the physiological stress caused by anesthesia and surgery. Close monitoring of the patient showed no signs of hypoadrenocorticism crises.

At the present study, two of the patients received $5 \mathrm{mg} / \mathrm{kg}$ bolus of hydrocortisone acetate right before submitting to the surgery; one dog received the $5 \mathrm{mg} / \mathrm{kg}$ bolus and was also put under hydrocortisone acetate CRI $(5 \mathrm{mg} / \mathrm{kg} / \mathrm{H})$. One patient did not receive the bolus application and was placed on hydrocortisone acetate CRI on a $5 \mathrm{mg} / \mathrm{kg} / \mathrm{H}$ rate. There was no complication found tied to receiving a source of corticoid supplementation pre or trans operative when compared to the 9 patients that did not receive any.

All patients at the present study received prednisone $(0.6 \pm 0.4 \mathrm{mg} / \mathrm{kg}, \mathrm{PO}, \mathrm{q} 24 \mathrm{hr})$ for only 3 to 7 days, starting at the surgery's next day. None of the dogs presented hypofunction or failure of the contralateral adrenal gland verified by the general state of the dogs and follow up serum cortisol analysis.

The main complaints in the post-surgical rechecks were persistence of polyuria and polydipsia (10) observed up to the current level of circulating glucocorticoids decrease sufficiently so that it no longer impacts glomerular filtration rate and renal tubular reabsorption of water and also the action of antidiuretic hormone (ADH) is regularized. Schwartz et al. (2008) also observed this clinical alteration and reported an average persistence of up to 71 days after adrenalectomy. In 2008, Peláez et al. have also reported persistence of polyuria, polydipsia and polyphagia for up to four weeks after adrenalectomy. The present study found that four of the 13 animals presented persistent polyphagia over the postsurgical appointments (22 \pm 7 days). Another alteration commonly seen in adrenalectomy post-surgery is emesis, as also quoted by Barrera et al. (2013) and Lang et al. (2011), four of the dogs within this study presented emesis during the few first days after the procedure. The hyporexia also presented may be related to pain and discomfort during the first few days after surgery, and is not mentioned by any author as a relevant effect.

Like evidenced Schwartz et al. (2008), Lang et al. (2011) and Massari et al. (2011), the results of the histopathological analysis in this study demonstrate the prevalence of adrenal cortical adenoma found in 11 dogs, followed by only two cases of adenocarcinomas. On the other hand, Barrera et al. (2013) reported that out of 86 cases analyzed during their study, 45 were adrenocortical adenocarcinoma and only 14 cases were adrenocortical adenoma.

Adrenalectomy is the main therapeutic indication for the hyperadrenocorticism cases ACTH non-dependent and related to primary adrenal neoplasms. The main expectation regarding the procedure, when successful, is curing the condition of hypercortisolemia. However, recurrence of contralateral adrenal hyperfunction after a certain period is a fact already observed in a very few studies. A research by Van Sluijs et al. (1995) suggested the incidence of hypercortisolemia recurrence months after having the adrenalectomy performed. Of the 26 dogs in the study that underwent adrenalectomy, eight had hyperfunction recurrence by the contralateral adrenal confirmed. The same fact was also observed by Lang et al. (2011), who reported an occurrence of $12 \%$ of 60 cases analyzed developing recurrence of the condition. In the present study, two dogs had recurrence of the hypercortisolemia associated with contralateral adrenal hyperplasia (both right sided), 5 and 11 months' post-adrenalectomy. Only one dog underwent CT during the investigation of its case, with the images suggestive of adrenal tumor. None of them had ACTHendogenous analysis before surgery and only one was submitted to the dexamethasone suppression test, highlighting the need for a more thorough investigation when it comes to additional complementary tests for the ideal candidates' selection when adrenalectomy is the treatment of choice.

Adrenalectomy is generically associated with a high perioperative mortality rate in dogs (SCHWARTZ et al., 
2008; LANG et al., 2011). However, the present study revealed the death of only one of the 13 dogs directly related to the procedure and during postoperative period. Massari et al. (2011) states that dogs that survive the postoperative period reach, in most cases, good results with average survival time greater than 10 months. Of the remaining 12 animals in the present study, one death was found 27 months after the adrenalectomy due to unrelated reasons. Nine of the animals are currently healthy in general, with the longest post-adrenalectomy survival period found to date of three years. The two dogs with recurrent hypercortisolemia condition are currently being treated with trilostane to control the condition and post-adrenalectomy mean survival period for both are 2.6 years \pm 6 months until the study's conclusion.

\section{References}

ANDRADE, N.; RIVAS, L. R.; MILOVANCEV, M.; RADLINSKY, M. A.; CORNELL, K.; SCHMIEDT, C. Intercostal approach for right adrenalectomy in dogs. Veterinary Surgery, v. 43, n. 2, p. 99-104, 2014. doi: 10.1111/j.1532-950X.2014.12105.x.

BARRERA, J. S.; BERNARD, F.; EHRHART, E. J.; WITHROW, S. J.; MONNET, E. Evaluation of risk factors for outcome associated with adrenal gland tumors with or without invasion of the caudal vena cava and treated via adrenalectomy in dogs: 86 cases (1993-2009). Journal of the American Veterinary Medical Association, v. 242, n. 12, p. 1715-1721, 2013. doi: 10.2460/javma.242.12.1715.

BEHREND, E. N.; KOOISTRA, H. S.; NELSON, R.; REUSCH, C. E.; SCOTT-MONCRIEFF, J. C. Diagnosis of spontaneous canine hyperadrenocorticism: 2012. ACVIM consensus statement (small animal). Journal of Veterinary Internal Medicine, v. 27, n. 6, p. 1292-1304, 2013. doi: 10.1111/jvim.12192.

BRÖMEL, C.; NELSON, R. W.; FELDMAN, E. C.; MUNRO, C. J.; KASS, P. H.; VICO, A. E.; LABELLE, P.; CONLEY, A. J.; Serum inhibin concentration in dogs with adrenal gland disease and in healthy dogs. Journal of Veterinary Internal Medicine, v. 27, n. 1, p. 76-82, 2013. doi: 10.1111/jvim.12027.

CAPEN, C. C. The endocrine glands. In: MAXIE, M. G. Jubb, Kennedy, and Palmer's pathology of

\section{Final considerations}

Adrenalectomy can be considered a safe procedure, with few trans and postoperative complications, apart from the possibility of hypercortisolism recurrence. This situation can be prevented by previous additional complementary tests.

\section{Acknowledgements}

The authors would like to express our appreciation to the Anhembi Morumbi University - PIBIC/AM program and to the entire staff at the Anhembi Morumbi Veterinary Hospital for making this project possible and for all your support. We are thankful to our collegue Renata Castilho who provided great assistance in the research.

domestic animals. 5. ed. Ontario: Elsevier, 2007. v. 3, p. 407-425.

DAVIS, M. K.; SCHOCHET, R. A.; WRIGLEY, R. Ultrasonographic identification of vascular invasion by adrenal tumors in dogs. Veterinary Radiology and Ultrasound, v. 53, n. 4, p. 442-445, 2012. doi: 10.1111/j. 1740-8261.2011.01911.x.

FELDMAN, E. C. Hiperadrenocorticismo. In: ETTINGER, S. J.; FELDMAN, E. C. Tratado de medicina interna veterinária: doenças do cão e do gato. 5. ed. Rio de Janeiro: Guanabara Koogan, 2008. p. 1539-1568.

FOSSUM, T. W. Adrenalectomy. In: FOSSUM, T. W. Small animal surgery. 4. ed. Philadelphia: Mosby Elsevier, 2013. p. 633-637.

FRANKOT, J. L.; BEHREND, E. N.; SEBESTYEN, P.; POWERS, B. E. Adrenocortical carcinoma in a dog with incomplete excision managed long-term with metastasectomy alone. Journal of the American Animal Hospital Association, v. 48, n. 6, p. 417-423, 2012. doi: 10.5326/jaaha-ms-5800.

IIZUKA, T.; KAMATA, M.; YANAGAWA, M; NISHIMURA, R. Incidence of intraoperative hypotension during isoflurane-fentanyl and propofol-fentanyl anaesthesia in dogs. The Veterinary Journal, v. 198, n. 1, p. 289-291, 2013. doi: 10.1016/j.tvjl.2013.06.021. 
KYLES, A. E.; FELDMAN, E. C.; DE COCK, H. E.; KASS, P. H.; MATHEWS, K. G.; HARDIE, E. M.; NELSON, R. W.; ILKIW, J. E.; GREGORY, C. R. Surgical management of adrenal gland tumors with and without associated tumor thrombi in dogs: 40 cases (1994-2001). Journal of the American Veterinary Medical Association, v. 223, n. 5, p. 654-662, 2003. doi: 10.2460/javma.2003.223.654.

LANG, J. M.; SCHERTEL, E.; KENNEDY, S.; WILSON, D.; BARNHART, M.; DANIELSON, B. Elective and emergency surgical management of adrenal gland tumors: 60 cases (1999-2006). Journal of the American Animal Hospital Association, v. 47, n. 6, p. 428-435, 2011. doi: 10.5326/JAAHA-MS-5669.

MASSARI, F.; NICOLI, S.; ROMANELLI, G.; BURACCO, P.; ZINI, E. Adrenalectomy in dogs with adrenal gland tumors: 52 cases (2002-2008). Journal of the American Veterinary Medical Association, v. 239, n. 2, p. 216-221, 2011. doi: 10.2460/javma.239.2.216.

NAAN, E. C.; KIRPENSTEIJN, J.; DUPRÉ, G. P.; GALAC, S.; RADLINSKY, M. G. Innovative approach to laparoscopic adrenalectomy for treatment of unilateral adrenal gland tumors in dogs. Veterinary Surgery, v. 42, n. 6. p. 710-715, 2013. doi: 10.1111/j.1532-950X.2013.12029.x.

NELSON, R. W. Distúrbios da Glândula Adrenal. In: NELSON, R. W.; COUTO C. G. Medicina interna de pequenos animais. 4. ed. Rio de Janeiro: Mosby Elsevier, 2010. p. $812-838$.

PELÁEZ, M. J.; BOUVY, B. M.; DUPRÉ, G. P. Laparoscopic adrenalectomy for treatment of unilateral adrenocortical carcinomas: technique, complications, and results in seven dogs. Veterinary Surgery, v. 37, n. 5, p. 444-453, 2008. doi: 10.1111/j.1532-950X.2008.00410.x.

RUFFATO, M.; NOVELLO, L.; CLARK, L. What is the definition of intraoperative hypotension in dogs? Results from a survey of diplomates of the ACVAA and ECVAA. Veterinary Anaesthesia and Analgesia, v. 42, n. 1, p. 55-64, 2015. doi: 10.1111/vaa.12169.

SCHIMMER, B. P.; PARKER, K. L. Hormônio adrenocorticotrófico; esteróides adrenocorticais e seus análogos sintéticos; inibidores da síntese e das ações dos hormônios adrenocorticais hormonais. In: BRUNTON, L. L.; LAZO, J. S.; PARKER, K. L. Goodman \& Gilman: as bases farmacológicas da terapêutica. 11. ed. New York: McGraw-Hill; São Paulo: Artmed, 2007. p. 1433-1457.

SCHWARTZ, P.; KOVAK, J. R.; KOPROWSKI, A.; LUDWIG, L. L.; MONETTE, S.; BERGMAN, P. J. Evaluation of prognostic factors in the surgical treatment of adrenal gland tumors in dogs: 41 cases (1999-2005). Journal of the American Veterinary Medical Association, v. 232, n. 1, p. 77-84, 2008. doi: 10.2460/javma.232.1.77.

VAN SLUIJS, F. J.; SJOLLEMA, B. E.; VOORHOUT, G.; VAN DEN INGH, T. S. G. A. M.; RIJINBERK, A. Results of adrenalectomy in 36 dogs with hyperadrenocorticism caused by adrenocortical tumour. Veterinary Quarterly, v. 17, n. 3, p. 113-116, 1995. doi: 10.1080/01652176.1995.9694547.

WISE, I. K.; BOVERI, S. Anaesthetic management of a unilateral adrenalectomy of an adrenocortical tumour in a dog. Open Veterinary Journal, v. 6, n. 1, p. 62-67, 2016. doi: 10.4314/ovj.v6i1.9. 